greater proportion of the project's funds to applied science.

Another force for stability comes from a recently formed alliance among CONACYT and two bodies representing the scientific community: the president's Science Advisory Council (CCC) and the Mexican Academy of Sciences. This alliance produced the text of legislation overhauling Mexico's system of research funding (see Nature 397, 553; 1999), and also helped to obtain a 1997 presidential decree exempting research materials from import taxes.

CONACYT itself seems to have a programme - often newly minted - to address almost any gripe that one hears from the community. Do young scientists have difficulty setting up laboratories? Last year, CONACYT set up a programme of infrastructure grants for young scientists. Is peer review within Mexico inadequate? CONACYT is considering increasing the number of reviews from Spanish-speaking scientists abroad. Do new fields have trouble gaining a foothold? The Knowledge and Innovation Project has a special programme of support for emerging fields.

\section{Escaping a vicious circle}

But as well-intentioned and energetic as CONACYT officials may be, they can do little in the short term about the problem that surfaces in just about every conversation with a Mexican scientist - the small size of the Mexican research community. In a country of almost 100 million people, to have only around 4,500 researchers in natural sciences and engineering is unfortunate, but to be producing only about $300 \mathrm{PhDs}$ a year in these fields is simply depressing. Many scientists identify a vicious circle, comprising a research community that is too small to solve national problems, leading to a lack of public support for science, which in turn prevents growth of the community.

President Zedillo's administration, and the World Bank, are hoping that private-sector investment in $\mathrm{R} \& \mathrm{D}$, coaxed into life by the Knowledge and Innovation Project,

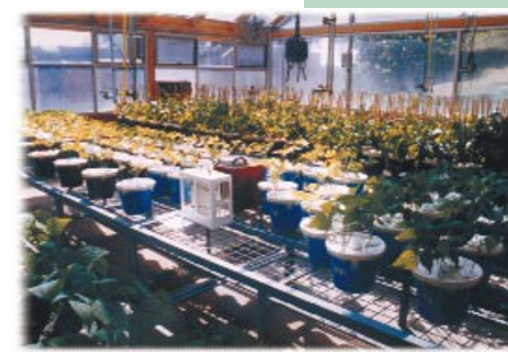

A greater focus on farming is sought by UNAM's nitrogen fixation centre.
The challenge of combining high-quality basic research with a mission to address the country's wider needs is embodied in the experience of UNAM's Nitrogen Fixation Research Centre, in Cuernavaca. The centre was founded in 1980 with the aim of studying the molecular basis of biological nitrogen fixation, and applying this knowledge to improve agriculture.

For the Mexican farmer, fertilizer is expensive to buy and transport, and its overuse is a significant environmental problem. Fertilizer use could be greatly reduced if the symbiosis between legumes and nitrogen-fixing bacteria could be improved or extended to crop plants other than legumes. And ultimately, if genetic engineering could give plants their own nitrogen-fixing apparatus, the need for bacteria could be eliminated.

In basic science, the centre has fulfilled its promise: its scientists have made important contributions to understanding the dynamics of the bacterial genome, the taxonomy of the bacterium Rhizobium and the carbon and nitrogen metabolism of bacteria and their host plants. As of the end of 1997, the centre - which currently has 12 full professors and 14 assistant professors - had contributed 130 papers to international journals, with about 2,200 citations.

So far, however, these discoveries have not been accompanied by corresponding improvements in Mexican agriculture. Part of the problem, says the centre's director, Georgina Hernández, is slow overall progress in this area of research. "What people thought would be possible 15 years ago turned out not to be so easy," she says.

"Genetically engineered bacteria have performed better in the laboratory and

two-thirds of R\&D spending.) This would require a quintupling of industrial spending, relative to GDP, with only a 50 per cent increase in government spending. R\&D will provide the missing ingredient that spending figures are not yet available for the turns the vicious circle into a virtuous one. The administration's six-year plan for science and technology made a commitment to increasing $R \& D$ spending from 0.32 per cent of the gross domestic product (GDP) in 1995 to 0.7 per cent in 2000 - but it envisaged that additional spending by industry would account for two-thirds of this increase, rising from 18 to 45 per cent of total R\&D spending. (In the United States, industry accounts for years after 1995, but there is no sign that any such industrial kick-start has occurred.

If optimists foresee a virtuous circle, pessimists recall the roller-coaster of past economic crises, together with the unpredictable swings of government policy. But there are reasons to hope that the future will be different. Although the economic crisis of 1994 is still taking its toll on R\&D spending, the effects have been nothing like those of the the greenhouse, but there have been problems with their ecology, and their survival in the field."

But some plant biologists from other Mexican institutes think that the centre's scientists have been too consumed with striving for academic excellence to pay attention to applied research. "They had the philosophy that applied research is not good for science," says one. Another, who is disappointed that the centre has not done more to help farmers, expresses a similar view: "They are excellent scientists. They could do better if they would just focus their brilliant brains on applications."

Hernández, who became the centre's director two years ago, acknowledges that most of its founding scientists had little or no experience of applied research. But she insists that what others interpret as a lack of interest in applications was instead a reluctance to undertake applied projects that did not have a solid grounding in fundamental research.

Whatever the reason for past reluctance, Hernández has been improving the balance between basic and applied research by encouraging collaborations with agronomists and growers. For example, strains of Rhizobium etli that have been genetically engineered to fix more nitrogen are being tested as inoculants of different bean varieties grown in Mexico, in field trials organized jointly with INIFAP, the Ministry of Agriculture's research institute.

In another new project, scientists from the centre are studying free-living nitrogen-fixing bacteria that associate with non-leguminous plants, such as sugar cane. A group of sugar cane producers is funding work to identify varieties that can derive sufficient nitrogen from bacteria to grow with little or no applied fertilizer.

crisis of 1982-83, which led to an exodus of scientists that is still apparent today, as a 'lost generation' of researchers. Mexican politics is more democratic and less corrupt than it has ever been - conditions that bode well for the stability that science needs to flourish.

Ultimately, however, the success of the scientific enterprise in Mexico will depend on the ability of Mexican scientists - by words and deeds - to convince not just the government, but also the Mexican public, that scientific research is as important to the country's well-being as education, health or social justice. In the words of René DruckerColín, a neurophysiologist at UNAM, "the Argentinian Nobel prizewinner Bernardo Alberto Houssay said that Argentina was too poor to have the luxury of not investing in science. The same applies here." 